\title{
Membingkai Teknologi Komputasi Awan: Perspektif Wartawan
}

\begin{abstract}
ABSTRAK
Tahun 2011 merupakan era baru teknologi komputasi awan (Cloud Computing).

Teknologi komputasi awan adalah solusi teknologi informasi dan komunikasi yang memberikan kesempatan kepada konsumen untuk dapat menyewa layanan teknologi dari penyedia (provider). Penyedia memberikan jasa pengelolaan infrastruktur, platform, dan aplikasi jasa teknologi informasi sehingga memudahkan konsumen tanpa harus berinvestasi. Hanya saja, ketika media baik media massa cetak dan media online menyebarluaskan informasi tentang teknologi komputasi awan, yang terjadi adalah penggunaan istilah-istilah teknologi yang berada pada level pakar (expert sphere) yang sulit dimengerti oleh masyarakat luas. Analisis yang digunakan adalah tiga kategori teknologi komputasi awan seperti Platform as a Service (PaaS), Infrastructure as a Service (IaaS), dan Software as a Service (SaaS); dua lapisan dari model Arnold Pacey seperti lapisan pakar (expert sphere) dan pengguna (user sphere) dalam pemanfaatan teknologi; dan dua pendekatan dari Arnold Pacey tentang pendekatan obyek (object approach) dan manusia (human approach). Dengan metode analisis isi diperoleh bahwa pemberitaan tentang teknologi komputasi awan lebih banyak pada kategori PaaS, expert sphere, dan object approach. Kemudian penelitian ini memperlihatkan adanya kecenderungan penggunaan bahasa dan tulisan wartawan yang tidak seimbang. Dengan menggunakan analisis framing, penelitian ini memperlihatkan adanya bingkai tertentu yang dilakukan oleh wartawan dalam menulis artikel dan berita terkait dengan teknologi komputasi awan.
\end{abstract}

Kata kunci: Teknologi Komputasi Awan, Level Pakar dan Pengguna, Pendekatan Obyek dan Manusia, Bingkai Media

\section{PENDAHULUAN}

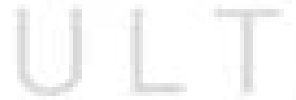

Tahun 2011 adalah babak baru era transisi teknologi informasi dan komunikasi (TIK) dari komputasi berbasis klien atau server menuju ke komputasi awan atau cloud computing. Berbeda dengan komputasi klien atau server, komputasi awan memungkinkan konsumen untuk menyewa layanan teknologi dari provider seperti software, penyimpanan, platform infrastruktur dan aplikasi layanan teknologi melalui jaringan internet. Dengan layanan komputasi awan, konsumen hanya menggunakan layanan sesuai yang dibutuhkan dan membayar sesuai layanan yang dipakai. 
Teknologi komputasi awan menguntungkan konsumen karena konsumen tidak perlu lagi mengeluarkan investasi besar-besaran untuk software dan aplikasi data, penyimpanannya dan perawatannya. Babak baru perkembangan komputasi awan ini ditandai dengan aksi penggelontoran dana investasi besar-besaran dari pemain-pemain besar TIK seperti IBM, Intel, Google, Fujitsu, dan Microsoft untuk mengembangkan bisnis komputasi awan.

Dikatakan babak baru karena transisi menuju cloud computing pada dasarnya sudah dimulai sejak tahun 1960 ketika John McCarthy (1960) memperkirakan suatu hari komputasi akan menjadi infrastruktur publik seperti listrik dan telepon. Visi tersebut kemudian dilanjutkan oleh Larry Ellison (1995) yang memunculkan ide network computing. Kualitas jaringan komputer yang belum memadai membuat network computing ditinggalkan. Baru kemudian di era 1990-an awal muncul konsep Application Service Provider (ASP) yang memungkinkan pemilik data centre menawarkan fasilitas 'hosting' aplikasi yang dapat diakses pelanggan melalui jaringan computer (Falahuddin, 2010).

Lebih lanjut, jargon atau istilah cloud computing sendiri mulai menggema di industri TIK pada tahun 2005 terutama sejak namanama besar di dunia TIK seperti Amazon.com meluncurkan Amazon Elastic Compute Cloud (EC2), kemudian Google dengan google app engine, dan IBM dengan Blue Cloud Initiative. Babak demi babak transisi ini kemudian sampai pada tahun 2011 ketika IBM pada tanggal 7 Maret 2011 yang lalu mengumumkan investasi sebesar US\$38 Miliar untuk membangun pusat data yang dinamai "IBM Asia Pacific Cloud Computing Data Centre" di Singapura. Tidak main-main, fasilitas baru ini menambah kemampuan IBM sebagai jaringan pelayanan awan global yang terintegrasi dengan pusatpusat IBM lainnya seperti Jerman, Kanada, dan Amerika Serikat. Integrasi juga mencakup 13 laboratorum awan global yang dimiliki IBM, yang tujuh di antaranya ada di Asia Pasifik -
China, India, Korea, Jepang, Hong Kong, Vietnam dan Singapura (IBM, 2011).

Sementara itu, Fujitsu juga menginvestasikan dana US\$1.1 Miliar sekaligus melakukan pelatihan kepada 5.000 spesialis teknologi komputasi awan hingga akhir 2012 untuk mengembangkan infrastruktur komputasi awan Fujitsu "Infastructure as a Service" (IAAS). Dengan fasilitas IAAS yang sudah ada sebelumnya, pelayanan komputasi awan Fujitsu telah menghasilkan US\$ 14 juta. Dengan pengembangan yang masih terus berjalan, Fujitsu menargetkan bisa mendapatkan revenue dari bisnis layananan komputasi awan sebesar US\$ 17 Miliar pada tahun 2016 (www.fujitsu.com, 2011).

Meski tidak menyebutkan jumlah investasinya, nama besar lain seperti Google dan Intel juga sudah mengarahkan gerbong bisnisnya menuju pengembangan layanan cloud computing. Jika Google sudah bersiap dengan sistem operasi Cloud Chrome OS (Falahuddin, 2010), Intel juga menetapkan pergeseran menuju komputasi awan dalam visi Intel's Cloud 2015 melalui Intel Cloud Builder (Intel, 2010). Dalam visi ini komputasi awan difederasi, diotomatisasi dan sadar akan kliennya. Terfederasi artinya komunikasi, data, dan layanan dapat berpindah secara mudah di dalam maupun melintasi infrastruktur komputasi awan. Terotomatisasi artinya layanan dan sumberdaya komputasi awan dapat ditetapkan, ditempatkan dan disiapkan secara aman hampir tanpa interaksi manusia. Sementara yang dimaksud dengan sadar klien adalah aplikasi yang berbasis awan dapat secara dinamis memahami dan memberi keuntungan pada penggunanya dengan cara mengoptimalkan kemampuan device yang dimiliki klien dan meningkatkan kapabilitas layanan dengan cara yang aman (Intel, 2010).

Jika beberapa pemain besar sedang mulai membangun dan memantapkan infrastrukturnya untuk menuju era komputasi awan, Microsoft mengaku bahwa secara keseluruhan (all in) sudah berada di awan (Harms \& Ya- 
martino, 2010). Microsoft sudah mulai melangkah dengan layanan komersial "Software as a Service" (SaaS) dengan Office 365 dan platform komputasi awan yang disebut "Windows Azure Platform". Office 365 menonjolkan aplikasi yang familiar dengan pelanggan misalnya pertukaran e-mail dan kolaborasi sharepoint melalui awan milik Microsoft. Sementara "Windows Azure" merupakan platform komputasi awan yang memungkinkan pelang gan untuk membangun sendiri aplikasinya dan mengoperasikan IT-nya dengan cara aman dan terukur di dalam awan. Membentuk aplikasi yang terukur dan sempurna tidak mudah, oleh karena itu Microsoft membangun "Windows Azure" dengan memanfaatkan keahlian ahli di Microsoft dalam membangun aplikasi yang memaksimalkan awan, misalnya "Office 365 ", "Bing" dan "Windows Live Hotmail" (Foley, 2011). Tidak hanya sekedar memindahkan mesin virtual ke dalam awan, Microsoft juga membangun platform sebagai layanan yang mengurangi kompleksitas pengembang dan administrator teknologi informasi (Harms \& Yamartino, 2010).

Dalam pengembangan komputasi awan nya Microsoft juga membangun hubungan dengan 600.000 rekanan yang tersebar di sekitar 200 negara (Harms \& Yamartino, 2010). Microsoft juga telah melayani jutaan bisnis dan berkolaborasi dengan ribuan rekanan di dalam transisi awan. Demi mengembangkan layanan komputasi awan yang paling aman, paling bisa diandalkan, paling tersedia dan paling terukur, Microsoft gencar mengadakan pengenalan dan edukasi teknologi komputasi awan di negara-negara yang bekerja sama dengan Microsoft, salah satunya Indonesia (Harms \& Yamartino, 2010).

Tidak banyak yang tahu jika di Indonesia Microsoft telah melakukan pengenalan teknologi komputasi awan tidak hanya untuk dunia bisnis tetapi juga di dunia pendidikan. Sutanto Hartono (2010) mengatakan bahwa Microsoft membantu edukasi di Indonesia untuk menuju era digital dalam mewujudkan knowledge base society. Salah satu kerjasama yang dibangun adalah bersama dengan Primagama. Primagama saat ini telah mengadopsi layanan cloud computing dari Microsoft secara keseluruhan yang terdiri dari infrastruktur, platform, dan software karena menggunakan server Microsoft (Zuhri, 2011). Bahkan untuk memperkuat sosialisasi teknologi komputasi awan di Indonesia, Microsoft Indonesia juga menyelenggarakan kompetisi penulisan jurnalistik teknologi komputasi awan. Dengan menggunakan tema "komputasi awan" diharapkan reporter sebagai ujung tombak sosialisasi dengan menggunakan media dapat memberikan penjelasan yang baik tentang komputasi awan. Hal ini dikatakan oleh Zuhri (2011) bahwa komputasi awan bukan hal baru dalam sektor teknologi informasi dan komunikasi, namun bagi masyarakat umum yang tidak terlalu bersinggungan dengan TIK, komputasi awan merupakan hal yang baru.

Selama ini, teknologi komputasi awan belum banyak dimengerti oleh masyarakat awam dan terus dianggap sebagai barang baru yang sulit untuk dipahami. Hal ini salah satunya diakibatkan oleh pemberitaan media massa baik media konvensional maupun media baru (online) di Indonesia yang memberitakan komputasi awan yang ditengarai menggunakan bahasa yang berada pada level expert sphere atau level pakar. Sehingga artikel-artikel yang muncul menggunakan istilah-istilah teknologi yang hanya dimengerti oleh orang yang berkecimpung di dunia TIK. Padahal media dianggap sebagai saluran yang digunakan untuk membuat masyarakat melek terhadap teknologi (technological literacy). Media dianggap sebagai bagian dari sistem edukasi informal yang menyediakan kesempatan untuk masyarakat untuk mempelajari dan menjadi terlibat dalam beragam isu yang berhubungan dengan teknologi. Media dianggap memiliki dampak yang bisa diukur dalam membuat khalayak memperoleh pengetahuan di bidang ilmu pengetahuan dan teknologi (Miller, 2002). 
Penyebarluasan informasi tentang teknologi komputasi awan, yang dilakukan oleh media massa di Indonesia masih sering menggunakan istilah-istilah yang berada pada level pakar karena umumnya reporter yang meliput kegiatan-kegiatan yang terkait dengan teknologi komputasi awan di Indonesia seringkali tidak memiliki latar belakang TIK. Selain itu seringkali media yang memberitakan teknologi komputasi awan adalah media massa umum yang tidak memiliki segmentasi di bidang TIK. Sehingga jika di dalam media massa umum yang tidak segmentasi TIK muncul liputan-liputan komputasi awan yang menggunakan bahasa level pakar, maka pembaca umum yang tidak memiliki latar belakang TIK menjadi sulit memahami komputasi awan tersebut. Karena pemilihan kata, kalimat dan frase yang kurang sesuai dengan kebutuhan informasi khalayak umum yang notabene tidak semuanya memiliki dasar TIK, maka fungsi media yang membuat masyarakat melek teknologi sulit terpenuhi.

Beranjak dari permasalahan tersebut maka penelitian ini mencoba menggali lebih dalam model dan jenis pemberitaan tentang teknologi komputasi awan yang dimuat oleh media massa baik itu media cetak atau media online. Adapun permasalahan dalam penelitian ini diuraikan secara lebih rinci adalah: (1) media-media apa saja yang memberitakan perkembangan teknologi komputasi awan di Indonesia? (2) bagaimana media-media tersebut memberitakan teknologi komputasi awan? (3) bagaimana perbandingan lapisan (sphere) pada pemberitaan teknologi komputasi awan dalam pemberitaan media-media tersebut?

Pertanyaan penelitian yang diajukan terkait dengan tujuan dan signifikansi penelitian ini. Tujuan penelitian ini adalah untuk mengetahui jenis media yang memberitakan perkembangan teknologi komputasi awan di Indonesia, mengetahui kategori-kategori yang dibuat oleh media terkait dengan pemberitaan teknologi komputasi awan dan mengetahui perbandingan lapisan (sphere) yang terdapat dalam pemberitaan teknologi komputasi awan di media massa dan online. Kemudian signifikansi teoritis dan akademis yang terkait bahwa belum adanya pengkajian teknologi komputasi awan secara konseptul dari perspektif teknologi komunikasi khususnya dari perspektif media yang spesifik kepada reporternya. Sementara dalam konteks signifikansi praktis, penelitian memperlihatkan perlu adanya perubahan dalam gaya penulisan reporter terkait dengan pemberitaan dan peristiwa teknologi.

\section{KERANGKA PEMIKIRAN}

Penelitian ini menggunakan tiga konsep pemikiran untuk menganalisis pemberitaan teknologi komputasi awan. Konsep pemikiran yang pertama menjelaskan mengenai komputasi awan. Kemudian konsep pemikiran kedua menjelaskan budaya teknologi komputasi awan dan konsep pemikiran ketiga menjelaskan mengenai agenda setting teknologi komputasi awan yang kemudian dijadikan dasar untuk melakukan framing.

\section{Teknologi Komputasi Awan}

Komputasi awan muncul karena meningkatnya tuntutan permintaan pusat data (data center) dengan kapasitas tinggi dan sumberdaya yang semakin terintegrasi. Permintaan ini dibarengi dengan meningkatnya kebutuhan untuk mengelola pertumbuhan bisnis dan meningkatnya fleksibilitas TIK (Harms \& Yamartino, 2010). Untuk memenuhi kebutuhan tersebut, komputasi awan berkembang secara bertahap dalam dua bentuk. Pertama dalam bentuk awan publik (public cloud) yang dikembangkan oleh perusahaan internet, telekomunikasi, provider layanan hosting dan sebagainya. Bentuk yang kedua adalah awan pribadi atau awan perusahaan (private cloud or enterprise cloud) yang dikembangkan oleh perusahaan-perusahaan dengan menggunakan firewall untuk penggunaan internal organisasi (Intel, 2010).

Selain tuntutan permintaan pusat data dan sumberdaya yang terintegrasi, teknologi komputasi 
awan juga muncul karena adanya pergeseran yang mendasar dalam ekonomi TIK. Komputasi awan membuat standarisasi dan mengumpulkan sumberdaya TIK serta mengotomatisasi beberapa tugas dan fungsi yang selama ini masih dikerjakan secara manual. Desain awan memfasilitasi konsumsi secara elastis dan fleksibel, layanan mandiri, dan harga yang sesuai dengan penggunaan fasilitas. Komputasi awan juga memungkinkan infrastruktur TIK yang paling mendasar dapat diubah menjadi pusat data yang luas, sehingga secara ekonomis, komputasi awan memberikan tiga keuntungan (Intel, 2010).

Keuntungan teknologi komputasi awan yang pertama adalah penghematan dari sisi supply, yaitu pusat data yang berskala luas (Large-data centers -DC's) dapat menghemat biaya yang dikeluarkan untuk server. Yang kedua pengkombinasian dari sisi permintaan. Pengkombinasian permintaan dari komputasi untuk melancarkan komunikasi memungkinkan peningkatan pemanfaatan server. Sementara yang terakhir adalah efisiensi multi sewa ( $m u l$ ty-tenancy) (Intel, 2010) . Ketika berganti ke dalam model aplikasi yang multi sewa, maka komputasi awan dapat menghemat biaya yang dikeluarkan untuk sewa dan pengelolaan aplikasi (Harms \& Yamartino, 2010).

Secara praktis, komputasi awan memberikan keuntungan karena sifat dasar komputasi awan adalah menggunakan pusat data yang besar sehingga bisa menyebarkan sumberdaya komputasi dengan biaya yang jauh lebih murah dari pada menggunakan pusat data yang lebih kecil. Selain itu permintaan penyatuan (pooling) dalam suatu pusat data yang luas memungkinkan peingkatan pemanfaatan sumberdaya, terutama dalam awan publik (public cloud). Kemudian penyedia sewa aplikasi yang multisewa (multy-tenancy) dapat menghemat biaya tenaga kerja dan perawatan aplikasi. Komputasi awan juga menjanjikan penawaran yang elastis dan ketangkasan yang memungkinkan berkembangnya solusi dan aplikasi baru (Intel, 2010).

Komputasi awan memiliki layanan yang dapat dibagi menjadi tiga segmen. Segmen tersebut adalah software (perangkat lunak), platform, dan infrastruktur. Masingmasing segmen ini memiliki tujuan berbeda dan menawarkan produk yang berbeda untuk bisnis dan individu di seluruh dunia. Layanan yang pertama adalah Software as a Service (SaaS), yaitu layanan yang berbasis pada konsep menyewakan software dari sebuah provider layanan sehingga pelanggan tidak perlu membeli software. Dari SaaS, industri berpindah menuju Platform as a Service (PaaS) yang menawarkan pengembangan platform untuk para developer. Pengguna layanan ini membuat kode mereka sendiri, kemudian provider PaaS mengunggah dan menampilkannya di web. PaaS menyediakan layanan untuk mengembangkan, menguji, menyebarkan, menjadi host dan menjaga aplikasi di dalam lingkungan pengembangan yang sama. Segmen terakhir dari komputasi awan adalah Infrastructure as a Service (IaaS) yang memungkinkan pengguna komputasi awan untuk membeli infrastuktur berdasarkan kebutuhan mereka. Keuntungannya adalah pengguna hanya membayar layanan sesuai dengan yang mereka gunakan, sehingga tidak perlu membayar mahal untuk membeli layanan yang pada dasarnya jarang digunakan (cloudtweaks.com, 2011).

\section{Budaya Teknologi}

Konsep teknologi Arnold Pacey dapat digunakan untuk memahami budaya teknologi komputasi awan. Pacey (2000) membantu meluruskan pemahaman tentang teknologi di era sebelumnya yang selalu diasosiasikan dengan mesin. Menurut Pacey, teknologi memiliki tiga aspek. Aspek pertama adalah aspek organisasi yang merepresentasikan keran-keran administrasi, kebijakan publik yang berhubungan dengan aktifitas desainer, insinyur, teknisi, pekerja, dan juga kepedulian kepada pengguna dan konsumen. Aspek kedua adalah aspek teknikal yang berhubungan dengan mesin, 
teknik pengetahuan dan hal-hal penting lainnya yang memungkinkan teknologi dapat berjalan. Kedua aspek ini bersamaan dengan beragam keyakinan dan kebiasaan berpikir yang merupakan karakter dari aktivitas teknis dan ilmiah dapat diindikasikan sebagai aspek budaya dari teknologi.

Kemudian, Pacey (2000) juga melihat adanya aspek organisasional yang mencakup aktivitas ekonomi, industri, professional, pengguna dan konsumen. Sementara aspek teknis mencakup pengetahuan, keahlian dan teknik, peralatan, mesin, bahan kimia, sumberdaya, produk dan limbahnya. Sedangkan aspek kultural mencakup tujuan, nilai dan kode etik, keyakinan pada kemajuan, kesadaran dan kreativitas. Dalam sebuah teknologi, selalu ada aspek teknis yang dapat menimbulkan masalah misalnya kerusakan alat atau teknologi terlalu sulit untuk digunakan. Kemudian di tingkat organisasi, sering kali ada kesulitan dalam perawatan (maintenance) teknologi. Kemudian teknologi selalu memiliki aspek budaya, yaitu teknologi yang diciptakan sesuai dengan budaya (keyakinan dan kebiasaan berpikir) para pencipta teknologi. Dari ketiga aspek ini maka dari segi utilisasi, teknologi dapat dibedakan menjadi dua, yakni ruang ahli/pakar (expert sphere) dan pengguna (user sphere).

Dengan menggunakan model Arnold Pacey (2000) mengenai tiga aspek teknologi dan dua sphere teknologi, maka penelitian ini menggali pemberitaan teknologi komputasi awan di media massa Indonesia. Berdasarkan tiga aspek teknologi Pacey, idealnya pemberitaan di media massa mengenai teknologi komputasi awan juga mencakup ketiga area ini. Namun pada kenyataannya baik dari penciptaan, pelayanan maupun ulasan di media sering kali terjadi ketimpangan antara ketiga area tersebut. Begitu pula dengan pembagian ruang teknologi pada ulasan media. Ulasan teknologi pada media harus mengakomodasi kedua ruang, baik expert dan user secara proporsional. Adanya dua lapisan: pakar (expert sphere) dan pengguna (user sphere) dalam pemanfaatan teknologi, penelitian ini bermaksud membedah pemberitaan-pemberitaan media massa di Indonesia mengenai teknologi komputasi awan. Dengan dua sphere Pacey, penelitian ini bermaksud mencari tahu kecenderungan penggunaan bahasa dan tulisan wartawan yang tidak seimbang antara bahasa expert sphere dan user sphere. Sesuai konsep Pacey, idealnya penulisan artikel teknologi komputasi awan pada media massa di Indonesia tidak hanya dibatasi pada hal teknis, namun juga memperhatikan dimensi lain seperti politik, sosial, dan ekonomi untuk menyelaraskan ruang expert dan ruang user dalam ulasan di media.

Kemudian dari tiga aspek teknologi, Pacey (2001) juga mengungkapkan adanya dua pendekatan pada teknologi yaitu pendekatan objek (object approach) dan pendekatan manusia (human approach). Perbedaan antara pendekatan obyek dan pendekatan manusia muncul karena adanya dua ide dasar yang ada. Di satu sisi, ada komitmen yang nyata pada kemanusiaan dan niat yang benar-benar murni berpusatkan pada kehidupan para ilmuwan dan insinyur. Namun di sisi lain ada antusiasme dan dorongan yang berhubungan dengan mesin yang berkekuatan tinggi, yang membuat pola visual dan eksplorasi yang sama sekali tidak memiliki kaitan langsung dengan hal-hal yang berhubungan dengan manusia (Pacey, 2001).

\section{Agenda Setting Teknologi Komputasi Awan}

Teori agenda setting yang dikemukakan oleh Maxwell Mc Combs dan Donald Shaw (1972) adalah salah satu teori tentang proses dampak media atau efek komunikasi massa terhadap masyarakat dan budaya. Teori ini termasuk dalam Phase 3 dari The Primes $O f$ Media Effect yakni Powerful Media Rediscovered (McQuail, 2000). Agenda setting menggambarkan kekuatan pengaruh media yang sangat kuat terhadap pembentukan opini masyarakat."... media massa dengan memberikan perhatian pada isu tertentu dan mengabaikan yang lainnya, akan memiliki pengaruh terhadap pendapat umum. Orang akan cenderung 
mengetahui tentang hal-hal yang diberitakan media massa dan menerima susunan prioritas yang diberikan media massa terhadap isu-isu yang berbeda" (Sendjaja, 2000: 1999). Media massa memiliki kemampuan untuk memberitahukan kepada masyarakat atau khalayak tentang isu-isu tertentu yang dianggap penting dan kemudian khalayak tidak hanya mempelajari dan memahami isu-isu pemberitaan tapi juga seberapa penting arti suatu isu atau topik berdasarkan cara media massa memberikan penekanan terhadap isu tersebut.

Jadi sesuatu yang dianggap penting dan menjadi agenda media maka itu pulalah yang juga dianggap penting dan menjadi media bagi khalayak. Menurut Bernard Cohen, "The press may not be successful much of the time in telling its readers what to think, but it is stunningly successful in telling its readers what to think about" (1963: 13). Untuk itu, media melakukan seleksi sebelum melaporkan berita kemudian melakukan gatekeeping terhadap informasi. Kemudian media membuat pilihan terhadap sesuatu yang akan diberitakan. Dengan demikian sesuatu yang diketahui oleh khalayak pada umumnya merupakan hasil dari media gate keeping (Shoemaker \& Vos, 2009).

Ada tiga proses agenda setting : Pertama, media agenda yaitu ketika isu didiskusikan dalam media. Kedua, public agenda yaitu ketika isu didiskusikan dan secara pribadi sesuai dengan khalayak. Ketiga, policy agenda yaitu pada saat para pembuat kebijaksanaan menyadari pentingnya isu tersebut. Secara umum, ketiga proses agenda setting saling terkait satu sama lain, agenda media dapat mempengaruhi agenda publik, dan agenda publiklah yang nantinya akan menentukan agenda kebijakan. Namun, saling berkaitannya variabel-variabel tersebut bisa jadi tidaklah linear, melainkan bisa timbal balik, hanya besar dan luasnya tingkat keterpengaruhan itu bisa dijadikan bahan kajian lanjut (McQuail, 2000).

Kekuatan media banyak bergantung kepada hubungannya dengan pusat kekuasaan. Jika media erat hubungannya dengan para elit kekuasaan, maka akan terpengaruh oleh kekuasaan, dan media agenda juga bisa terpengaruh olehnya. Sehingga keadaan ini membuat media bisa menjadi bagian dari ideologi dominan dalam masyarakat, dan jika ini terjadi, maka pada gilirannya ideologi dominan tersebut akan merembes ke dalam agenda publik. Jadi media massa mempunyai kemampuan untuk memilih dan menekankan topik tertentu yang dianggapnya penting (menetapkan 'agenda') sehingga membuat publik berpikir bahwa isu yang dipilih media itu penting (McQuail, 2000).

Eksplorasi pada efek agenda setting telah mengobservasi fenomena komunikasi massa dari berbagai perspektif. Salah satunya adalah tipologi Acapulco (McCombs, 1981 dalam McCombs, 2005) yang dapat digunakan untuk menerangkan agenda setting. Tipologi Acapulco terdiri dari dua dimensi, yaitu dimensi pertama, fokus pada keseluruhan itemitem yang paling mengartikan suatu agenda kemudian dimensi kedua, membagi pengukuran kesesuaian agenda media dengan agenda publik menjadi dua, mendeskripsikan pengukuran keseluruhan grup atau populasi atau mendeskripsikan pengukuran secara individu (McCombs, 2005).

Tipologi Acapulco juga terdiri dari empat perspektif; yaitu perspektif pertama, dari perspektif agenda media, nilai kepentingan dari sebuah isu dapat dilihat dari jumlah total artikel yang membahas tentang isu tersebut. Kemudian dari perspektif publik, dapat dilihat berdasarkan jumlah khalayak yang "tergerak" setelah isu tersebut dijadikan perhatian publik. Selanjutnya perspektif kedua, hampir sama dengan perspektif pertama, hanya pada perspektif ini fokusnya lebih pada agenda publik secara individu. Sedangkan perspektif ketiga, fokus pada tingkat koresponden antara agenda media dan agenda publik yang naik turun berdasarkan waktu. Terakhir perspektif keempat, fokus pada individu di tingkat kepentingan tunggal agenda (McCombs, 2005).

Agenda setting menggambarkan kekuatan pengaruh media yang sangat kuat dalam 
pembentukan opini masyarakat. Media massa mempunyai kemampuan untuk memilih dan menekankan topik tertentu yang dianggapnya penting (menetapkan 'agenda' / agenda media) sehingga membuat publik berpikir bahwa isu yang dipilih media itu penting dan menjadi agenda publik. Menurut teori Agenda Setting ada tiga proses agenda setting yakni media agenda, public agenda dan policy agenda (McCombs, 2005). Pada penelitian ini teori agenda setting difokuskan untuk melihat agenda media.

\section{METODOLOGI}

Penelitian ini menganalisis pemberitaan media di Indonesia baik cetak maupun online mengenai teknologi komputasi awan selama periode November 2010 hingga Februari 2011. Periode ini berdasarkan periode yang digunakan oleh Microsoft Indonesia dalam melakukan kompetisi penulisan jurnalistik teknologi komputasi awan. Pengumuman periode ini telah dilakukan pada bulan Maret 2011 yang lalu. Kemudian dengan menggunakan metode analisis isi yang dikembangkan dalam analisis framing, penelitian ini memperlihatkan adanya bingkai tertentu yang dilakukan oleh wartawan dalam menulis artikel dan berita terkait dengan teknologi komputasi awan. Untuk memudahkan pengumpulan data melalui studi literatur yaitu menganalisa artikel, maka dipergunakan kategorisasi dan penggunaan indikator atau kata kunci. Kategorisasi dan kata indikator ini dibuat sesuai dengan permasalahan penelitian.

Dalam permasalahan penelitian terdapat tiga pertanyaan yang dapat dijawab dengan menggunakan pendekatan-pendekatan yang dijabarkan dalam kerangka konsep. Untuk menjelaskan cara media-media di Indonesia memberitakan teknologi komputasi awan digunakan dua kategori. Kategori pertama adalah pendekatan atau fokus yang memiliki dua indikator yaitu fokus pada obyek yang menjelaskan bahwa artikel lebih menekankan pada aspek teknis perkembangan teknologi, dan fokus pada manusia yang menjelaskan bahwa artikel lebih menekankan pada pengembangan kemampuan manusia dengan adanya teknologi. Kategori kedua adalah layanan yang terbagi dalam tiga indikator yaitu Platform as a Service (PaaS), Software as a Service (SaaS) dan Infrastructure as a Service (IaaS) yang menjelaskan kecenderungan media massa Indonesia dalam membahas layanan komputasi awan. Kategori terakhir yaitu kategori lapisan digunakan untuk menjawab pertanyaan perbandingan lapisan (sphere) pada pemberitaan teknologi komputasi awan di media massa. Kategori ini memiliki dua indikator yaitu lapisan pengguna (user sphere) dan lapisan ahli (expert sphere) yang dapat menganalisa kecenderungan pemberitaan artikel komputasi awan di Indonesia.

Setelah data kualitatif telah terkumpul seluruhnya, selanjutnya dilakukan pengkodean. Analisis data dilakukan pada setiap kode atau kategori. Dalam penelitian ini digunakan dua koder yang masing-masing menghasilkan coding dari seluruh artikel yang dianalisis. Kemudian hasil kategori dari dua koder diuji reliabilitasnya dengan menggunakan rumus Holsti (1969). Coefisien reliabilitas (CR) diperoleh dengan pembagian dari jumlah pernyataan yang disetujui oleh dua coder (M) dengan jumlah objek yang dikategorikan (Holsti, 1969).

Dari hasil perhitungan coefisien reliabitas, maka ditemukan observed agreement yang diperoleh dari penelitian. Hasil pengujian reliabilitas antar coder dengan rumus Hostli memperlihatkan angka 0.96 yang berarti bahwa terdapat 96 persen tingkat kesepakatan yang terjadi antara dua coder. Hasil pengkodingan yang tidak sesuai antara kedua coder dikeluarkan dari analisis. Kemudian dari hasil yang terbanyak secara kuantiatif (frekuensi tertinggi) dari setiap kategori dipilih masingmasing tiga artikel menjadi bahan dasar untuk melakukan framing. Pemilihan tiga artikel dari masing-masing kategori berdasarkan pada tiga artikel yang berada pada tiga rangking di atas yang sering muncul di setiap kategori.

Metode framing yang digunakan 
adalah model Pan dan Konsicki. Hal ini disebabkan karena model Pan dan Konsicki (2001) berasumsi bahwa setiap berita mempunyai frame yang berfungsi sebagai pusat dari organisasi ide. Frame ini merupakan suatu ide yang dihubungkan dengan elemen yang berbeda dalam teks berita, seperti kutipan sumber, latar informasi, pemakaian kata atau kalimat tertentu, ke dalam teks secara keseluruhan. Dalam pendekatan ini, perangkat framing dibagi ke dalam empat struktur besar. Pertama, struktur sintaksis, berhubungan dengan cara wartawan menyusun fakta berdasarkan peristiwa, pernyataan, opini, kutipan, pengamatan atas peristiwa. Pengamatan dilakukan pada headline, lead, latar belakang informasi, kutipan sumber, pernyataan, dan penutup. Kedua, struktur skrip atau terkait dengan kelengkapan berita. Hal ini berhubungan dengan wartawan mengisahkan atau menceritakan peristiwa ke dalam bentuk berita. Pengamatan kelengkapan berita dilihat dari what, who, where, when, why $(5 \mathrm{~W})$ dan how (1H). Kemudian selanjutnya yang ketiga adalah struktur tematik. Hal ini berhubungan dengan cara wartawan mengungkapkan pandangannya atas peristiwa. Pengamatan dilakukan ketika wartawan mengisahkan fakta secara detail, koherensi, bentuk kalimat, dan kata ganti. Indikatornya adalah adanya pernyataan dalam paragraf, preposisi, kalimat atau hubungan antar kalimat yang membentuk teks secara keseluruhan. Yang terakhir atau keempat adalah struktur retoris. Bagian ini berhubungan dengan cara wartawan menekankan fakta dengan arti tertentu ke dalam berita. Pengamatan dilakukan pada leksikon, grafis, dan metafora. Indikator dilihat dari kata, idiom, gambar/foto, dan grafik. Dalam analisisnya, keempat struktur tersebut merupakan rangkaian yang dapat menunjukan framing dalam suatu media (Pan \& Kosicki, 2001; Eriyanto, 2002).

\section{HASIL DAN DISKUSI}

Dari hasil penelusuran artikel mengenai teknologi komputasi awan selama periode November hingga Februari 2011, terdapat 23 media yang disepakati memberitakan secara khusus tentang teknologi komputasi awan. Sesuai dengan pertanyaan pertama, maka penelitian ini memperlihatkan bahwa terdapat 10 media online $(43,49 \%)$ dan $13(56,51 \%)$ diantaranya adalah media cetak. Dari 13 media cetak yang mengulas mengenai teknologi komputasi awan ini, hanya ada satu $(7,69 \%)$ yang berasal dari majalah, sementara $12(92,31 \%)$ lainnya adalah surat kabar.

Kemudian dari 23 media massa yang dianalisis, terkumpul dan disepakati 35 artikel yang membahas teknologi komputasi awan. Untuk menganalisa artikel-artikel ini digunakan tiga kategori yang dapat digunakan untuk menjawab pertanyaan kedua dalam penelitian ini. Kategori pertama adalah kategori fokus atau pendekatan yang terbagi menjadi dua indikator yaitu fokus atau pendekatan pada obyek dan fokus atau pendekatan pada manusia. Kategori kedua adalah kategori layanan, yaitu PaaS, SaaS, dan IaaS. Kedua kategori ini digunakan untuk menjawab pertanyaan penelitian cara media-media memberitakan teknologi komputasi awan. Kemudian kategori yang ketiga adalah kategori lapisan (sphere) yaitu lapisan ahli (expert sphere) dan lapisan pengguna (user sphere), yang digunakan untuk menjawab pertanyaan penelitian yang ketiga, yaitu perbandingan lapisan (sphere) pada pemberitaan teknologi dalam pemberitaan media massa di Indonesia.

\section{Fokus atau Pendekatan Pemberitaan Komputasi Awan}

Untuk kategori pertama, yaitu fokus artikel, dari 35 artikel terdapat 26 artikel (74,3\%) yang berfokus pada cloud computing sebagai obyek dan praktek penggunaannya. Sementara itu artikel yang lebih memfokuskan pada manusia sebagai pengguna yang dapat meningkatkan kemampuan dengan teknologi ini hanya ada sembilan (9) artikel $(25,7 \%)$. Contoh artikel yang memokuskan pada objek teknologi komputasi awan adalah artikel di media yang berjudul "Microsoft Cloud Summit 2011: Mi- 
crosoft Cloud Road to Prepare For Consumers" (thepresidentpost.com, 2011). Dari segi sintaksis, artikel ini memiliki lead dan headline yang orientasinya lebih ke obyek teknologi daripada unsur manusia. Berikut adalah cuplikan lead artikel ini,
"Microsoft once again proves that the com- pany's software development of cloud com- puting.Microsoft has more than 15 years experience in cloud computing and has a total commitment to develop...." (thepres- identpost.com, 21 Januari 2011).

Dari awal, artikel ini sudah lebih merujuk kepada obyek komputasi awan dibanding peningkatan kemampuan manusia dengan komputasi awan. Contoh lead lain yang lebih merujuk kepada objek daripada manusia adalah artikel dari media online yang berjudul "Microsoft Lync Diperkenalkan di Pasar Indonesia" (SWA-Online.com, 2010). Berikut adalah lead artikel ini,

\begin{abstract}
"Apakah perusahaan anda sudah mengaplikasikan Microsoft Lync?Jika belum, ada kabar baik karena per 17 Nopember 2010, konsumen bisnis di Indonesia dapat mengunduh versi percobaan Lynch secara cuma-cuma...dan dapat dibeli di pasaran..."(SWA-Online.com, 16 November 2010).
\end{abstract}

Cuplikan artikel di atas alih-alih bersifat informatif dengan fokus manusia dapat memanfaatkan teknologi untuk meningkatkan kemampuan, namun ternyata justru seperti kalimat awal sebuah iklan mengenai teknologi baru. Selain cenderung berpromosi, artikel ini sangat fokus pada objek teknologi. Contoh artikel lain yang lebih cenderung mengarah pada obyek adalah artikel media online yang berjudul "Microsoft Reaches for Clouds With Indonesia Ambitions" (thejakartaglobe.com, 2011) dengan lead sebagai berikut,

"Software giant Microsoft is looking to invest around \$2,5 billion in Indonesia to develop cloud computing system....cloud computing in which vast data banks and program can be eccesed remotely using a personal comuter connected to the..." (thejakartaglobe.com, 21 Januari 2011).

Ketiga contoh artikel dari "thepresidentpost.com", "Swa-Online" dan "the Jakarta Globe" menunjukkan bahwa secara sintaksis, dari lead dan headline menggambarkan body artikel yang lebih berfokus dari objek. Secara sintaksis, kecenderungan fokus pada objek juga diperlihatkan dari pernyataan penutup, misalnya kalimat penutup artikel "Microsoft Lync Diperkenalkan di Pasar Indonesia" yang berbunyi "Lync online termasuk menyediakan layanan pesan singkat, kehadiran secara maya/online, konferensi audio dan video serta telfon suara ..." (SWA-Online. com, 16 November 2010), atau pada pernyataan penutup artikel "Microsoft Reaches for Clouds With Indonesia Ambitions" yang berbunyi "Sharp said competing firms offering cloud services would drive companies like Microsoft to develop better technology and products.."'(thepresidentpost.com, 21 Januari 2011). Selain itu kutipan-kutipan dari sumber juga lebih fokus pada pendekatan obyek dari pada manusia, misalnya "Microsoft is very flexible, we designed a plan and a system according to the needs of every business..." (thepresidentpost.com, 21 Januari 2011). Hal yang sama seperti "Cloud computing is now the center of all the things we do...it's an evolution of virtualization..." (thejakartaglobe.com, 21 januari 2011).

Dari segi kelengkapan berita, ketiga artikel yang dianalisis ini memiliki unsur berita $5 \mathrm{~W}$ dan $1 \mathrm{H}$ yang lengkap dan memiliki pendekatan yang sangat fokus pada obyek. Umumnya unsur dalam artikel-artikel ini sama, yaitu unsur what adalah urgensi komputasi awan, unsur who adalah Microsoft atau pemilik layanan komputasi awan, unsur why adalah alasan-alasan yang menjelaskan urgensi komputasi awan, unsur when adalah tahun perkem- 
bangan komputasi awan dari tahun 2009 hingga 2011 dan unsur where adalah Indonesia sebagai lokasi yang dipandang urgent untuk mengembangkan komputasi awan. Sedangkan untuk unsur how cara penyebaran teknologi komputasi awan di Indonesia misalnya pada kalimat "kami dapat membangun solusi ini di atas sistem ini dan bekerja dalam jangkauan set sistem yang terluas.."(SWA-Online.com, 16 November 2010). Kemudian di media online tertulis,

"Through cloud summit participants can obtain the latest information about Cloud that delivered by a number of international expert speakers as well as to study the opportunity to begin to make the transition cloud, through a number of birds and plans..."(thepresidentpost.com, 21 Januari 2011).

Dari segi tematik atau cara wartawan menulis fakta dan dari segi retoris atau cara wartawan menekankan fakta, paragraf-paragraf yang digunakan dan kata-kata juga idiom juga lebih fokus pada pendekatan secara obyek. Misalnya saja "Microsoft once again proves that the company's software development world is the leader in the development of cloud computing..."'(thepresidentpost, 21 Januari 2011). Kemudian seperti pernyataan penutup "Now, all the company needs is a computer and broadband (to benefit from) cloud computing..." (thejakartaglobe.com, 21 Januari 2011), yang jelas-jelas tidak menggunakan pendekatan manusia sama sekali karena menekankan bahwa dalam era komputasi awan, yang dibutuhkan hanya sebuah komputer dan jaringan broadband, tanpa menyebut unsur manusia.

\section{Pemberitaan Layanan Komputasi Awan}

Kategori yang kedua adalah kategori layanan yang dapat digunakan untuk mengetahui kecenderungan artikel-artikel media massa dan online di Indonesia dalam membahas layanan komputasi awan. Hasil analisa menunjukkan bahwa dari 35 artikel terdapat 11 artikel
$(31,42 \%)$ yang mengupas semua tiga layanan yaitu platform as a service (PaaS), software as a service (SaaS), dan infrastruktur as a service (IaaS). Namun demikian, yang paling banyak menjadi fokus artikel dari sisi layanan komputasi awan adalah PaaS, yaitu sebanyak 28 artikel $(80 \%)$. Hal ini seperti artikel dari majalah SWA (9-19 Desember, 2010) yang berjudul "Komunikasi Mulus, Aset Migas Terurus".

Dari segi sintaksis, artikel "Komunikasi Mulus, Aset Migas Terurus" menggunakan lead dan headline yang jelas memfokuskan isi berita pada layanan komputasi awan PaaS. Misalnya saja headline artikel tersebut yang mengungkapkan "Dengan memadukan solusi ERP, BPM dan teknologi Unified communication, manajemen PT Medco E\&P Internasional tidak lagi kesulitan..."(SWA, Desember, 2010). Contoh lain artikel yang secara sintaksis lebih mengupas layanan PaaS adalah artikel yang berjudul "Jalin Komunikasi dengan Lync" (Koran Tempo, 2010). Headline dari artikel ini adalah, "Mengintegrasikan layanan pesan, audio, video, serta konferensi web dan suara...Microsoft Lync merupakan platform tunggal yang mengintegrasikan layanan pesan, kehadiran secara online, audio, video..."(KoranTempo, 2010).

Contoh lain artikel yang secara sintaksis yaitu dari headline dan lead lebih menekankan pada layanan PaaS adalah artikel surat kabar harian yang berjudul "Komunikasi Satu Platform saja" (Media Indonesia, 2010). Artikel ini memiliki lead sebagai berikut, "Waktu produktif pekerja bisa terkikis gara-gara mengirim e-mail, pesan singkat, dan menelepon dengan platform yang beragam..."(Media Indonesia, 20 November 2010).

Secara sintaksis, dari segi kutipan sumber artikel-artikel ini juga lebih menegaskan pada layanan PaaS misalnya artikel majalah SWA yang mengupas pengalaman PT MEPI dalam menggunakan PaaS komputasi awan yang tergambar dalam pernyataan "MEPI telah mengadopsi platfor teknologi Unified Communication (UC) dari salah satu vendor...dengan 
solusi UC ini, kami bisa melakukan kolaborasi kerja secara virtual, sekaligus menggantikan sistem PABX di kantor pusat..." (Swa, 9-19 Desember 2010). Contoh lain adalah kutipan dari General Manager of Information System Planning Departement Nikon Corp di Koran Tempo (2010) yang menegaskan keuntungan penggunaan layanan PaaS komputasi awan sebagai berikut,

"Penggunaan Microsoft Lync dengan sharePoint dan Exchange dapat meningkatkan produktifitas karyawan perusahaan...kami ingin bergerak lebih jauh lagi ketimbang hanya mengandalkan alat komunikasi tertentu seperti e-mail.." (Koran Tempo, 22 November 2010).

Dari segi sintaksis, jika dilihat melalui pernyataan penutup, ketiga artikel "Jalin Koneksi dengan Lynch" (Koran Tempo, 2010), "Komunikasi Satu Platform Saja" (Media Indonesia, 2010) dan "Komunikasi Mulus Migas Terurus" (SWA, 2010) juga sangat fokus kepada layanan PaaS. Hal ini terungkap dengan penutup yang menyatakan "cloud menjadi pilihan yang baik, perusahaan tak perlu repot-repot membangun server sendiri yang kompleks..,"(Media Indonesia, 20 November 2010). Kemudian penutup artikel yang menyatakan "melalui cloud computing... ini menjadi layanan komunikasi yang terintegrasi, murah, dan sederhana..."(Koran Tempo, 22 November 2010).

Dari segi kelengkapan berita, ketiga artikel yang dianalisis ini memiliki semua unsur $5 \mathrm{~W}+1 \mathrm{H}$. Umumnya yang menjadi unsur what dalam artikel adalah layanan komputasi awan PaaS. Kemudian yang menjadi unsur who adalah para pengguna yang telah berpengalaman menggunakan teknologi PaaS seperti PT MEPI atau Nikon Corp. Kemudian yang menjadi unsur why adalah alasan para pengguna dalam memanfaatkan layanan PaaS untuk bisnisnya, sedangkan unsur when adalah tahun 2010 dan unsur where adalah di Indonesia. Untuk unsur how, ketiga artikel yang dianalisis mengungkapkan cara pengimplementasian layanan PaaS dalam bisnis.

Dari segi tematik dan retoris artikel "Komunikasi Mulus, Aset Migas Terurus" (SWA, 2010) juga lebih berfokus pada PaaS. Hal ini diperlihatkan dengan paragraf-paragraf dan kata yang merujuk pada hal-hal yang hanya berhubungan dengan PaaS. Hal ini seperti pada kalimat "Pada solusi ERP mulai diimplementasikan sebagai backbone untuk semua transaksi..." (SWA, 9-19 Desember 2010) atau "Fungsi BPM ini sebagai workflow dan governance atas semua proses ..." (SWA, 9-19 Desember 2010) dan "melihat benefit dari platform UC berbasis OCS ini jauh lebih besar, maka..."(SWA, 9-19 Desember 2010). Demikian juga pada artikel "Komunikasi Satu Platform Saja" (Media Indonesia, 2010) yang banyak memunculkan kalimat-kalimat yang mengandung kata platform seperti “...di Amerika misalnya, seorang pekerja bisa sibuk sendiri dengan lima platform komunikasi..." (Media Indonesia, 20 November 2010), atau pada kalimat "... tak hanya mampu mengintegrasikan berbagai macam platform komunikasi, Lync juga menyajikan..." (Media Indonesia, 20 November 2010).

\section{Lapisan Ahli dan Pengguna dalam Artikel} Komputasi Awan

Berdasarkan kategorisasi mengenai lapisan pengguna teknologi yaitu user sphere dan expert sphere yang dioperasionalisasikan berdasarkan kerangka teori, maka dari 35 artikel yang terkumpul, 24 artikel $(68,57 \%)$ diantaranya menggunakan bahasa yang lebih mengacu pada expert sphere. Hanya 11 artikel $(31,43 \%)$ yang berada pada tataran $u$ ser sphere. Contoh artikel yang lebih mengacu pada expert sphere adalah artikel di media Online yang berjudul "Teknologi Komputasi Awan Mulai Digunakan Perusahaan Start Up" (SWA-Online, 15 Desember 2010). Secara sintaksis dari skema berita, headline, lead, hingga pernyataan penutup disusun dengan bahasa 
yang cenderung mengarah pada expert, salah satunya kalimat "...cloud memungkinkan biaya start-up yang rendah dan hilangnya investasi modal..." (SWA-Online, 15 Desember 2010). Pada paragraf sebelumnya artikel ini tidak menjelaskan konsep dasar awan dan definisi atau pemahaman mengenai start-up. Hal ini memperlihatkan bahwa artikel ini lebih ditujukan untuk pembaca yang berada pada lapisan atau level expert.

Contoh lain artikel berita yang secara sintaksis dari segi lead dan headline mengacu kepada lapisan ahli adalah artikel dari media cetak yang berjudul "Cloud Computing Yang Tidak Terbatas" (Media Indonesia, 24 Januari 2011) yang memiliki lead sebagai berikut, "Bagi pecinta film pasti sepakat film fiksi ilmiah avatar karya James Cameron memang luar biasa..." (Media Indonesia, 24 Januari 2011). Dari kalimat pertama saja artikel ini sudah mengerucutkan pembacanya dengan kalimat "bagi pecinta film pasti sepakat". Kemudian contoh kecondongan yang cukup jelas dapat dilihat pada artikel di media online kompas.com yang berjudul "Fleksibilitas Layanan Komputasi Awan" (Kompas.com, 20 Januari 2011) yang leadnya sebagai berikut,

"Layanan komputasi awan (cloud computing) menawarkan fleksibilitas kepada perusahaan untuk....dengan teknologi inilah perusahaan bisa memilih skala infrastruktur yang dibutuhkannya tanpa terbebani total cost ownership (TCO) atau ongkos investasi di awal' (Kompas.com, 20 Januari 2011).

Secara keseluruhan artikel-artikel yaitu "Fleksibilitas Layanan Komputasi Awan" (Kompas.com, 20 Januari 2011), “Teknologi Komputasi Awan Mulai Digunakan Perusahaan Start Up" (Swa-Online, 15 Desember 2010), dan "Cloud Computing Yang Tidak Terbatas" (Media Indonesia, 24 Januari 2011), ketiganya menggunakan sumber yang merupakan pemilik layanan, dan mitra pengembang layanan komputasi awan, bukan dari sisi pengguna yang sudah menggunakan teknologi ini. Dalam ketiga artikel ini, sumber yang digunakan umumnya berasal dari Microsoft Indonesia yang merupakan expert dari teknologi komputasi awan. Sumber lain juga adalah sumber yang ahli di bidang TIK seperti Analis dari VP Gartner.

Dari sintaksis berita dari segi pernyataan penutup, semua artikel ini menggunakan paragraph dan kalimat penutup yang sulit dipahami oleh pengguna awam. Misalnya saja pada artikel "Fleksibilitas Layanan Komputasi Awan" yang memiliki pernyataan penutup, "Biaya sebesar 112 miliar dollar AS akan dibelanjakan secara kumulatif untuk software as a service, platform as a service dan infrastructure as a service dalam kurun waktu 5 tahun mendatang (Kompas.com, 20 Januari 2011). Demikian juga pada artikel "Teknologi Komputasi Awan Mulai Digunakan Perusahaan Start Up" yang memiliki pernyataan penutup sebagai berikut, "Sifat Jangkauan solusi Microsoft pun mencakup Public Cloud, Private Cloud, dan Hybrid Cloud" (Swa-Online, 15 Desember 2010). Juga penutup pada artikel "Cloud Computing Yang Tidak Terbatas" yang menyatakan "Namun kalau untuk mengakses data-data seperti banking application, memang butuh internet berkecepatan tinggi" (Media Indonesia, 24 Januari 2011).

Dari segi skrip, artikel berita ini sudah memenuhi unsur $5 \mathrm{~W}$ dan $1 \mathrm{H}$. Umumnya yang menjadi unsur what adalah perkembangan komputasi awan, unsur who adalah layanan komputasi awan yang tidak terbatas, unsur why adalah alasan-alasan yang menjelaskan pentingnya komputasi awan, unsur when adalah tahun masuknya komputasi awan di Indonesia yaitu tahun 2010 dan unsur where adalah Indonesia sebagai lokasi perkembangan komputasi awan. Sedangkan untuk unsur how cara penyebaran teknologi komputasi awan di Indonesia.

Dari segi tematik dan retoris, fakta, kalimat yang digunakan, kata-kata juga idiom yang digunakan juga mengacu ke pembaca $e x$ pert. Kata-kata seperti cloud, start up, SaaS, 
PaaS, IaaS, Public Cloud, Private Cloud, dan Hybrid Cloud muncul dalam artikel "Teknologi Komputasi Awan Mulai Digunakan Perusahaan Start Up" (Swa-Online, 15 Desember 2010) tanpa ada penjelasan yang dapat digunakan pembaca yang awam untuk memahami kata-kata tersebut. Demikian juga kata-kata seperti kapasitas broadband dan banking application dan siapa atau apa VP Gartner yang muncul tanpa penjelasan dalam artikel "Cloud Computing Yang Tidak Terbatas" (Media Indonesia, 24 Januari 2011), akan membingungkan pembaca yang tidak mengikuti perkembangan TIK.

\section{KESIMPULAN}

Teknologi komputasi awan adalah salah satu solusi layanan TIK yang memungkinkan penggunanya menyewa layanan TIK dari penyedia jasa layanan (provider) baik itu layanan software, platform maupun infrastruktur. Perkembangan teknologi komputasi awan pada tahun 2011 semakin pesat dengan banyaknya investasi dari perusahaan-perusahaan besar yang bermain di industri TIK, misalnya Microsoft, Fujitsu, Google, IBM dan Intel. Tidak hanya di luar negeri, perkembangan teknologi komputasi awan juga sudah merambah Indonesia dengan banyaknya lembaga dan korporasi di Indonesia yang mulai menggunakan teknologi komputasi awan misalnya Primagama dan PT Medco E\&P Internasional.

Meskipun sudah banyak perusahaan yang menggunakan layanan komputasi awan, namun gaung komputasi awan di Indonesia, terutama di kalangan masyarakat awam belum begitu kencang terdengar. Padahal tidak menutup kemungkinan, perkembangan komputasi awan di Indonesia bisa sampai pada level pengguna individu, tidak hanya pada perusahaan besar saja. Hal ini disebabkan oleh penyebaran informasi tentang teknologi komputasi awan yang dilakukan oleh media massa cetak dan online di Indonesia masih sering menggunakan istilah-istilah yang kurang sesuai dengan kebutuhan informasi khalayak umum yang notabene tidak semuanya memiliki dasar TIK.

Hasil penelitian menunjukkan bahwa media yang dominan mengupas teknologi komputasi awan adalah surat kabar dan media online. Penelitian ini memperlihatkan juga cara media memberitakan teknologi komputasi awan yang kebanyakan masih memfokuskan pada komputasi awan sebagai obyek, bukan pada manusia sebagai pengguna komputasi awan yang dapat meningkatkan kemampuannya dalam berkomunikasi dengan menggunakan teknologi komputasi awan. Kemudian, sebagian besar artikel juga masih memfokuskan pokok bahasan pada Platform as a Service (PaaS), padahal perlu adanya keseimbangan dalam pemberitaan mengenai tiga layanan komputasi awan agar masyarakat memahami dengan baik layanan-layanan komputasi awan.

Hasil penelitian juga menunjukkan bahwa mayoritas artikel di Indonesia masih mengacu pada lapisan ahli (expert sphere). Dari lead, hingga kata-kata yang digunakan sampai sumber berita, sebagian besar masih berada di level expert padahal artikel tersebut ditulis oleh media yang pangsa pasarnya umum atau tidak tersegmentasi pada para ahli atau pakar TIK. Hal ini tentu meyurutkan minat pembaca untuk berusaha memahami lebih lanjut tentang teknologi komputasi awan. Kata-kata dan i diom yang tidak dijelaskan artinya tentu tidak akan dipahami oleh masyarakat awam.

Dari hasil penelitian ini, maka dapat disimpulkan bahwa informasi mengenai teknologi komputasi awan dalam pemberitaan pada media massa baik cetak maupun online di Indonesia masih belum seimbang, baik itu dari fokus bahasan yang masih memfokuskan pada teknologi sebagai obyek maupun informasi mengenai layanan. Selain itu pemberitaan di media massa juga masih cenderung mengacu pada lapisan ahli sehingga sulit dipahami oleh masyarakat awam. Hasil penelitian ini dapat digunakan sebagai rujukan bagi para pemangku kepentingan di media massa baik cetak 
maupun online dalam melakukan pemberitaan, sehingga masyarakat dapat mudah memahami teknologi komputasi awan. Idealnya, sebuah berita harus seimbang. Khususnya untuk pemberitaan mengenai teknologi, pemberitaan harus cover both side dari sisi lapisan pengguna (user sphere) maupun lapisan ahli (expert sphere).

\section{REFERENSI}

Cloudtweaks.com (2011) Unleashed cloud performance: Making the promise of cloud reality, diakses dari http://www. cloudtweaks.com/2011/03/unleashingcloud-performance-making-thepromise-of-cloud-a-reality/, tanggal 29 Maret 2011, pukul 08.00 WIB.

Cohen, B.C. (1963). The press and foreign pol icy. Princeton, NJ: Princeton.

de Vreese, C. H. (2005) News framing: Theory and typology, Information De sign Journal + Document Design, 13 (1), 51-62.

Eriyanto (2002), Analisis Framing, Yogyakar ta: LkiS.

Falahuddin, M.J. (2010) Lebih Jauh Mengenal Komputasi Awan, diakses dari http://www.detik.com/read/ 2010/02/24/lebih-jauh-mengenal-kom putasi-awan, tanggal 25 Maret 2011, pukul 14.00 WIB

Foley, Mary Jo. Microsoft Deliver Toolkit for Using Windows Azure to Build Windows Phone 7 Apps, diakses dari, http://www.zdnet.com/ microsoft/microsoft-deliver-toolkitfor-using-windows-azure-tobuild-windows-phone-7-apps/8993, tanggal 28 Maret 2011, pukul 16.00 WIB

Fujitsu.com (2011) Cloud computing to be come Fujitsu cornerstone strategy in 2011, diakses dari http://www.fujitsu. com/id/news/pr/20110125-en. html, tanggal 20 Februari 2011, pukul
12.31 WIB.

Harms, R., \& Yamartino, M. (2010) The eco nomics of clouds, Microsoft.

Holsti, O.R. (1969). Content Analysis for the Social Sciences and Humani ties. Reading, MA: Addison-Wesley.

IBM (2011) IBM invests US\$38M in cloud computing data centre to address Asia Pacific growth, diakses dari http://www-03.ibm.com/press/us/en/ pressrelease/33974.wss, tanggal 3 ma ret 2011, pukul 9.53 WIB.

Intel, (2010) Intel's vision of the ongoing shift to cloud computing: Executive summa ry, diakses dari www.intel.com/go/ cloud tanggal 24 Februari 2011 pukul $13.30 \mathrm{WIB}$

Janssen, M. C. (2005) A framing analysis of weblogs and online newspapers, tesis master, paper 3811, diakses dari http:// scholarworks.sjsu.edu/etd_the ses/3811, tanggal 21 Februari 2011, pu kul 15.00 WIB

McCombs, M. (2005). "A Look at agenda setting: Past, present and future." Jour nalism Studies 6, 4. 543-557.

McCombs, M., \& Shaw, D. (1972), The agen da-setting function of mass media, Public Opinion Quarterly, 36, 176-187.

McQuail, D. (2000). McQuail's mass commu nication theory (4th ed.).Thousand Oaks, CA: Sage Publications.

Miller, J. H. (2002) Get a life! The way we live (now and then): Paper disajikan pada the Digital Culture Workshop, Univer sity of California, Irvine, January 2003.

Pacey, A. (2000) Culture of technology, Bos ton: MIT Press.

Pacey, A. (2001) Meaning in technology, Bos ton: MIT Press.

Pan, Z., \& Kosicki, G. (2001) "Framing as Stra tegic Action" in Reese, S., Gandy, O., \& Grant, A., (eds.) Framing Public Life: Perspectives on Media and our under standing of the social world. Mahwah, 
N.J: Lawrence Erlbaum.

Reese, S. (2005). Framing Public Life: A Bridging Model for Media Re search dalam Reese,S., Gandy, O. \& Grant A. (eds), Framing Public Life: Perspectives on Media an dour Understanding of the Social World. Hillsdale, NJ: Lawrence Erl baum \&Associates. 7-33.

Reese, S. D. (2007) The Framing project: A bridging model for media research re visited. Journal of Communication 57: 148-54.

Scheufele, D. A. (1999) Framing as a theory of media effects, Journal of Communi cation, 103-123.
Scheufele, D. A., \& Tewksbury, D.(2007)

Framing, agenda setting, and priming: The evolution of three media effects models. Journal of Communication 57: 9-20.

Sendjaja, S. D., (2000) Teori Komunikasi, Ja karta, Jakarta: Universitas Terbuka.

Shoemaker, P. J., \& Vos, T. P., (2009) Gate keeping theory, New York: Routledge.

Weaver, D. H. (2007) Thoughts on agenda set ting, framing, and priming. Journal of Communication 57: 142-47.

Zhou, Y., \& Moy, P. (2007) Parsing framing processes: The interplay between on line public opinion and media cover age. Journal of Communication 57: 79-98.

Zuhri, (2011) Siapkah RI mengadopsi cloud computing, Bisnis Indonesia, Kamis 22 Januari 2011.
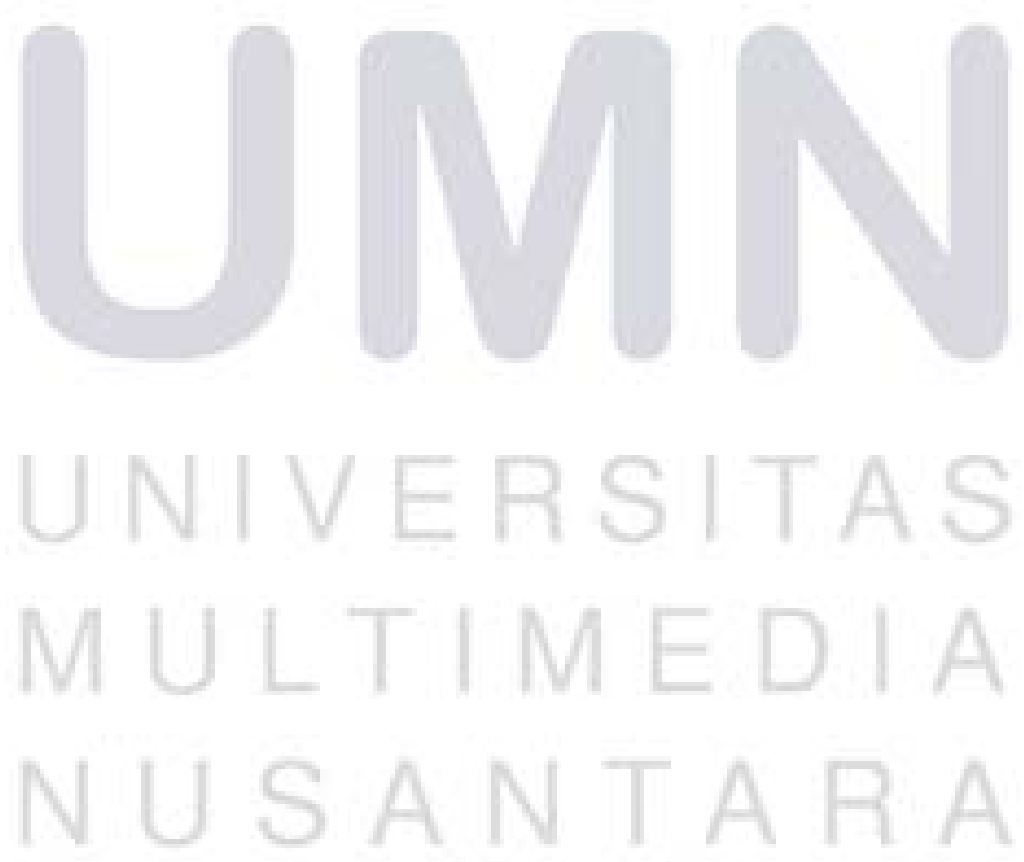